\title{
SENTENCE FRAGMENTS IN THE NARRATION OF THE NOVEL THE HUNGER GAMES
}

\author{
Farhani Nurhusna
}

\section{INTISARI}

Penggunaan fragmen kalimat pada umumnya tidak disarankan dalam penulisan Bahasa Inggris yang baik karena fragmen kalimat tidak memiliki satu atau lebih komponen penting dalam sebuah kalimat, yaitu subjek dan /atau predikat, dan oleh Karena itu itu tidak dapat diterima secara tata bahasa. Meskipun demikian dalam penulisa nfiksi, penggunaan fragmen kalimat cukup umum tidak hanya di dalam dialog, tetapi juga di dalam narasi.Studi ini menganalisis fragmen kalimat di dalam narasi novel The Hunger Games yang ditulis oleh Suzanne Collins, untuk menginvestigasi tipe-tipe fragmen yang digunakan di dalam novel danklasifikasi tipe tipe fragmen tersebut berdasarkan struktur sintaksis dalam bentuk fragmen klausa terikat dan fragmen frasa. Fragmen kalimat tersebut kemudian dianalisis untuk dicaritahu kegunaannya berdasarkan konteks dari kalimat-kalimat yang ditulis sebelum fragmen kalimat tersebut.Penggunaan fragmen kalimat di dalam novel ini pada dasarnya berfungsi untuk member penekanan pada poin-poin penting di dalam cerita.

Kata kunci: fragmenkalimat, tatabahasa, fragmenklausaterikat, fragmenfrasa, narasi.

\begin{abstract}
The use of sentence fragments is generally discouraged in good English writing because they lack one or more essential components of a sentence, namely a subject and/or a predicate, and thus are grammatically unacceptable. However in fiction writing, the use of sentence fragments is not only quite common in dialogue, but in narration as well. The present study analyses sentence fragments in the narration of the first novel of the young-adult science-fiction trilogy The Hunger Games written by Suzanne Collins, to investigate the types of fragments employed in the novel and their classification based on syntactic structure in the form of dependent-clause fragments and phrase fragments. The sentence fragments were further analysed for their use based on the context of their preceding sentences. The use of sentence fragments in the novel basically serves the function of creating emphasis or stressing important points in the story.
\end{abstract}

Keywords: sentence fragments, grammar, dependent-clause fragments, phrase fragments, narration. 


\section{INTRODUCTION}

In literature today it is common to find incorrect sentence structure not just in dialogue where it usually occurs, but in narration as well. Sentence fragments are an example of such incorrect sentence structure that are sometimes used intentionally by skilled authors for emphasis or effect. A sentence fragment is a set of words that is punctuated as a sentence even though it is not grammatically an independent sentence (Greenbaum\& Nelson, 2002). A sentence expresses a complete idea, but a fragment neglects to tell the reader either what it is about (the subject) or what happened (the verb) (Fulwiler\& Hayakawa, 2003).

The present study will investigate the use of sentence fragments in the first book of the trilogy The Hunger Games, the New York Times bestselling young-adult science-fiction novel originally published in 2008 by Scholastic. The novel is chosen for analysis due to the constant use of sentence fragments in it, which also appeals the writer of this study to find out if the use of sentence fragments employed in the novel is deliberate to create an emphasis or effect. This study aims to investigate what types of sentence fragments are employed and to classify them based on their syntactic structure. The study is limited to the sentence fragments in the narration of the novel and will not analyse sentence fragments that occur in the dialogue.

This subject of study is important because it could be another perspective that shows how sentence fragments still could be used in writing, especially in fiction. The fact that the novel The Hunger Games is riddled with sentence fragments and these sentences did not get edited by an editor before publication, just shows that sentence fragments could be accepted and should not be anymore seen as an incorrect sentence structure that should get edited just to follow the rules of good writing, and one of which is the use of correct grammatical sentence structure. Despite their incorrectness, sentence fragments still could be used in writing as a device to create an emphasis or effect that is usually necessary in fiction.

\section{PREVIOUS STUDIES}

Schuster (2006) examines the fifty essays in two volumes of The Best American Essays (published in 2001 and 2003 respectively), to investigate professional writers' use of sentence fragments in their essays. The Best American Essays is a series of compiled magazine articles published annually in the United States. To identify the fragments, he did not count any sentence fragments that occur in dialogue and did not consider imperative sentences, which are grammatically incomplete because they lack a subject, as fragments. He also did not consider elliptical verb phrases, in which the verb phrases are omitted, as fragments (Schuster, 2006, p. 78). After examining the contexts in which the writers use fragments, Schuster stated that there are a few rules for effective fragment use that these writers employ in their writing. Because of this effectiveness that the fragments create, he concluded that the value of sentence fragments should have a place and not be avoided in writing, as it could be a good writing technique to create emphasis.

\section{THEORETICAL FRAMEWORK}

\section{1) Dependent-clause Fragments}

According to Choy and Clark, a dependent-clause fragment is a group of words that contain both a subject and a predicate that are part of a main independent sentence but is detached from it with a period so it stands by itself. A dependent-clause fragment always begins with a subordinating conjunction. Kolln and Funk (2011) state that a dependentclause fragment can be classified into the 
following subtypes: adjectival-clause fragments, adverbial-clause fragments, and nominal-clause fragments.

\section{a. Adjectival-clause Fragments}

An adjective clause, also called a relative clause, is a clause introduced by a relative pronoun (who, which, that) or a relative adverb (when, where, why) that generally modifies a noun (Kolln\& Funk, 2011, p. 361). According to Choy and Clark, an adjectival-clause fragment serves the function of an adjective which describes a noun or pronoun in the detached main clause or sentence that precedes the fragment.

In the following made-up example, the adjectival-clause fragment begins with the relative pronoun who and describes the noun "aunties and uncles" in the sentence that precedes it:

(1) I got dragged around the whole night meeting aunties and uncles. Who I'm pretty sure can't remember my name anyway.

In the following made-up example, the adjectival-clause fragment begins with the relative adverb where and describes the situation in the school, which is the noun in the sentence that precedes it:

(2) Nate hates his current school. Where everyone is mean and he gets called fat.

\section{b. Adverbial-clause Fragments}

An adverbial-clause fragment serves the function of an adverb and begins with the subordinating conjunctions that are used to begin adverb clauses, which describe verbs by telling how (as if, as though), when (after, as, as soon as, before, until, when, whenever, while), where (where, wherever), why (because, in order that, since, so that), or under what conditions (although, as long as, even though, if, though, unless) the action occurs (Choy \& Clark, 2010, p. 96). The following is a made-up example of it:

(3) I couldn't go play with my friends. Because my overprotective parents grounded me from going out.

\section{c. Nominal-clause Fragments}

Nominal clauses are subordinate clauses that have a range of functions similar to that of noun phrases (Greenbaum\& Nelson, 2002, p. 282). Detached from its main or independent clause, a nominalclause fragment begins with a that-clause or a wh-clause and can function as direct object. In the following made-up example, the fragment begins with a that-clause and functions as direct object to the verb "realise" in its preceding sentence:

(4) They realise that the man can be a big-time threat to them. That he can take them all down easily.

\section{2) Phrase Fragments}

Stilman (1997) states that a phrase consists of a group of related words, but it does not qualify as a clause because it does not contain both a subject and a predicate (it may contain a noun, a verb or both, but these do not constitute a clause unless they are in a specific relation to each other). Like a dependent-clause fragment, a phrase fragment is detached from its main or independent clause so it stands on its own. In the following section, the subtypes of phrase fragments are discussed.

\section{a. Added-detail Fragments}

The added-detail fragment contains an example or other detail that adds information to the preceding sentence. Detached from the main or independent sentence, this fragment lacks both a subject and a predicate. It usually begins with 
especially, for example, for instance, like, such as, including, and except. The following is a made-up example of it:

(5) I've been to English-speaking countries. Such as, Australia, England, Singapore, and the United States.

\section{b. Appositive Fragments}

Choy and Clark state that an appositive is a phrase placed beside a noun to clarify that noun's meaning. Appositive is from the verb to appose, meaning "to place things beside each other". An appositive fragment is detached from the preceding noun so it stands on its own, looking as if it were a sentence. The following is a made-up example of it:

(6) The guy talking with Jake is a student. A law student with superior academic record and outstanding leadership skills.

In the example above, the fragment clarifies the noun "student" in its preceding sentence.

\section{c. Infinitive-phrase Fragments}

According to Choy and Clark, an infinitive is the combination of the word to plus a verb, such as to walk or to study. Although more words will follow to finish the phrase, there is not a main clause to finish the thought because the main close is detached from it. The following is a madeup example of it:

(7) She wants to go to the garden. To catch butterflies for her biology project.

\section{d. Missing-subject Fragments}

The missing-subject fragment has a missing subject and is detached from the main or independent sentence. It usually begins with a coordinating conjunction such as and, but, for, or, nor, so, yet, but it can also begin without it. The following is a made-up example of it:

(8) After having a heated argument with her parents, she left her house. And took a cab to a friend's place.

\section{e. Participial-phrase Fragments}

According to Choy and Clark, a participial phrase begins with a participle. A participle is a verb form that functions as an adjective. There are two kinds of participles. Present participles are formed by adding -ingto the main verb (e.g., laughing, waiting, talking). Past participles end in a -ed(e.g., laughed, waited, talked) or various past-tense forms of irregular verbs (e.g., slept,seen, sung). A participialphrase fragment stands on its own. The following is a made-up example of it:

(9) A school bus carrying twentyfive high school students crashed into a tunnel. Injuring the driver and fifteen students.

\section{f. Prepositional-phrase Fragments}

Choy and Clark (2010) state that prepositions are the short words in our language that show the position or relationship between one word and another such as on, near,by, under,behind, about, and so on. They are always placed in front of a noun or a pronoun. The noun or pronoun following the preposition is called the object of the preposition. The group of words containing the preposition and its object is called a prepositional phrase. As a fragment, a prepositional phrase is detached from its main sentence so it stands on its own.

In the following made-up example, the prepositional-phrase fragment begins with the preposition near: 
(10) Although it has been many years, Chase still remembers that street. Near the river bank.

The noun in the above example is "river bank". It is also the object of the prepositional phrase "near the river bank". In the following made-up example, the prepositional-phrase fragment begins with the preposition about:

(11) I totally had doubts. About my decision to leave the town I'd been born in.

\section{THE STUDY}

Overall, 138 sentence fragments were found in the narration of the novel The Hunger Games, consisting of 46 dependent-clause fragments (33\%) and 92 phrase fragments $(67 \%)$, as shown in Table 1 below.

Table 1. The Frequency of Sentence Fragments in the Narration of The Hunger

\section{Games.}

\begin{tabular}{|c|c|c|c|}
\hline Types & Subtypes & No. & \% \\
\hline \multirow{1}{*}{$\begin{array}{c}\text { Dependent-clause } \\
\text { Fragments }\end{array}$} & $\begin{array}{c}\text { Nominal-clause } \\
\text { Fragments }\end{array}$ & 18 & 13 \\
\cline { 2 - 4 } & $\begin{array}{c}\text { Adverbial-clause } \\
\text { Fragments }\end{array}$ & 16 & 12 \\
\cline { 2 - 4 } & $\begin{array}{c}\text { Adjectival-clause } \\
\text { Fragments }\end{array}$ & 12 & 9 \\
\hline \multirow{5}{*}{ Phrase Fragments } & $\begin{array}{c}\text { Appositive } \\
\text { Fragments }\end{array}$ & 33 & 24 \\
\cline { 2 - 4 } & $\begin{array}{c}\text { Missing-subject } \\
\text { Fragments }\end{array}$ & 18 & 13 \\
\cline { 2 - 4 } & $\begin{array}{c}\text { Participial-phrase } \\
\text { Fragments }\end{array}$ & 16 & 11 \\
\cline { 2 - 4 } & $\begin{array}{c}\text { Added-detail } \\
\text { Fragments }\end{array}$ & 12 & 9 \\
\cline { 2 - 4 } & $\begin{array}{c}\text { Prepositional- } \\
\text { phrase Fragments }\end{array}$ & 8 & 6 \\
\cline { 2 - 4 } & $\begin{array}{c}\text { Infinitive-phrase } \\
\text { Fragments }\end{array}$ & 5 & 3 \\
\hline \multirow{2}{*}{ Total } & 138 & 100 \\
\hline
\end{tabular}

This table suggests that the use of phrase fragment is more favoured than that of dependent-clause fragments. In the form of phrase fragments, appositive fragments occur most frequently with 33 occurrences (24\%), followed by missing-subjects fragments that occur 18 times (13\%), participial-phrase fragments that occur 16 times $(11 \%)$, added-detail fragments that occur 12 times (9\%), prepositional-phrase fragments that occur 8 times $(6 \%)$, and infinitive-phrase fragments that occur 5 times (3\%). Meanwhile in the form of dependent-clause fragments, nominalclause fragments occur most frequently with 18 occurrences (13\%), followed by adverbial-clause fragments that occur 16 times (12\%) and adjectival-clause fragment that occur 12 times $(9 \%)$.

The following section presents and discusses some examples of each type of sentence fragment that occur in the narration of the novel.

\section{1) Dependent-clause Fragments}

\section{a. Nominal-clause Fragments}

The nominal-clause fragment begins with a that-clause or a wh-clause. The occurrences of a nominal-clause fragment in the narration of the novel begin with a that-clause. Some examples are as follows:

(12) But she's [Prim] worried about me. That the unthinkable might happen (p. 15).

(13) "My thanks to the people of District Eleven," I say. I want them to know I know where it came from. That the full value of their gift has been recognized (p. 239).

(14) "What am I supposed to do? Sit here and watch you die?" I say. He [Peeta] must know that's not an option. That the audience would hate me (p. 275). 
Each fragment in the examples above gives important information to its preceding sentence and creates an emphasis to it. In example (12), the fragment describes what Prim, Katniss's little sister is worried about, and emphasises that the unthinkable might happen to Katniss. In example (13), the fragment describes what Katniss wants the people from District Eleven to know, and emphasises that the full value of the gift they gave her has been recognised. In example (14), the fragment describes what Peeta must know, and emphasises that the audience (who watches the Hunger Games) would hate Katniss if he lets her do nothing but sit there and watch him die.

\section{b. Adverbial-clause Fragments}

The adverbial-clause fragment begins with a subordinating conjunction. The occurrences of an adverbial-clause fragment in the narration of the novel begin with the subordinating conjunctions because, if, even if, when, and where. In the following examples, the fragments in the narration of the novel begin with the subordinating conjunction because:

(15) Maybe if I had thanked him [Peeta] at some point, I'd be feeling less conflicted now. I thought about it a couple of times, but the opportunity never seemed to present itself. And now it never will.Because we're going to be thrown into an arena to fight to the death (p. 32).

(16) There's only one good reason Haymitch could be withholding water from me. Because he knows I've almost found it (p. 169).

Each fragment in the examples above explains and emphasises a reason regarding its preceding sentence. In example (15), the fragment explains and emphasises why Katniss's opportunity to thank Peeta will never present. In example (16), the fragment explains and emphasises why Haymitch could be withholding water from Katniss.

In the following example, the fragment that occurs in the narration of the novel begins with the subordinating conjunctions if and emphasises a situation regarding its preceding sentence:

(17) "It's to the Capitol's advantage to have us divided among ourselves," he [Gale] might say if there were no ears to hear but mine. If it wasn't reaping day. If a girl with a gold pin and no tesserae had not made what I'm sure she thought was a harmless comment (p. 14).

In the example above, there are two fragments that refer to the first sentence which is the complete, main sentence detached from them. They emphasise the hypothetical situations Katniss describes in each fragment.

In the following example, the fragment that occurs in the narration of the novel begins with the subordinating conjunction when:

(18) I wonder about Peeta. Has he lasted through the day? I'll know in a few hours. When they project the dead's images into the sky for the rest of us to see (p. 153).

The use of the fragment in the example above creates a dramatic effect to what Katniss is about to know in a few hours, which is about whether Peeta has lasted through the day or not.

In the following example, the fragment that occurs in the narration of the 
novel begins with the subordinating conjunction where:

(19) "You're right. They're driving us to the lake," I say. Where there's no cover. Where they're guaranteed a bloody fight to the death with nothing to block their view (p. 327).

The two fragments in the example above emphasise the description of the location where Katniss refers to in the preceding sentence. They create a dramatic sense to the lake with those descriptions.

\section{c. Adjectival-clause Fragments}

The adjectival-clause fragment begins with a relative pronoun or a relative adverb, describing a noun or a pronoun in the preceding sentence. The occurrences of an adjectival-clause fragment in the narration of the novel begin with the relative pronouns which and who, and the relative adverb why. In the following example, the fragment that occurs in the narration of the novel begins with the relative pronoun which:

(20) He is already fighting hard to stay alive. Which also means that kind PeetaMellark, the boy who gave me the bread, is fighting hard to kill me (p. $60)$.

The fragment in the example above refers to its preceding sentence and emphasises it. It emphasises that Peeta, who is already fighting hard to stay alive, is also fighting hard to kill Katniss.

In the following example, the fragment that occurs in the narration of the novel begins with the relative adverb why and explains and emphasises the reason why Peeta took a beating to give Katniss the bread on that awful hollow day:
(21) It would explain another thing, too. Why Peeta took a beating to give me the bread on that awful hollow day (p. 301).

\section{2) Phrase Fragments}

\section{a. Appositive Fragments}

The appositive fragment consists of a phrase placed beside a noun in the preceding sentence, clarifying that noun's meaning. In the following example of an appositive fragment that occurs in the narration of the novel, the fragment describes the noun or object in its preceding sentence:

(22) I swing my legs off the bed and slide into my hunting boots. Supple leather that has molded to my feet (p. 4).

(23) I dropped my gaze, embarrassed, and that's when I saw it. The first dandelion of the year (p. 32).

(24) Peeta packs up our gear while I lay out a big meal. The rest of the rabbits, roots, greens, the rolls spread with the last bit of cheese (p. 325).

In example 22, the fragment describes the object "my hunting boots" in its preceding sentence, which is made of leather and has molded to Katniss's feet. In example 23, the fragment clarifies the object "it" in its preceding sentence, which is the first dandelion of the year. In example 24, the fragment describes what kind of "a big meal" in its preceding sentence. Katniss's use of fragment to make the description here creates vivid images of each object.

In other examples of an appositive fragment below, the fragments that occurs in the narration of the novel not only describes the object in their preceding sentence but also creates an emphasis to it:

(25) On other days, deep in the woods, I've listened to him 
[Gale] rant about how the tesserae are just another tool to cause misery in our district. A way to plant hatred between the starving workers of the Seam and those who can generally count on supper and thereby ensure we will never trust one another ( $\mathrm{p}$. 14).

(26) Not only is Peeta with the Careers, he's helping them find me. The simpleminded girl who has to be taken serious because of her eleven (p. 163).

In example 25, the fragment describes what the tesserae, tokens worth a very meager year's supply of grain and oil for one person, that Gale (Katniss's friend) rants about are. It also emphasises what they really are in the district according to Gale. In example 26, the fragment emphasises what Katniss thinks about herself, which is the simpleminded girl who has to be taken seriously because of her eleven, the score she gets in the Hunger Games which is the highest score of all the tributes.

\section{b. Missing-subject Fragments}

As its name suggests, the missing-subject fragment is missing a subject. It may begin with or without a conjunction. In the following example, the missing-subject fragment that occurs in the narration of the novel begins with the conjunction $o r$ :

(27) Prim named him Buttercup, insisting that his muddy yellow coat matched the bright flower. He hates me. Or at least distrusts me (p. 3).

The fragment in the example above is missing a subject and refers to the subject in its preceding sentence. It refers to the subject Buttercup, and emphasises that he distrusts Katniss. In the following example, the missing-subject fragment that occurs in the narration of the novel does not begin with a conjunction:

(28) So I learned to hold my tongue and to turn my features into an indifferent mask so that no one could ever read my thoughts. Do my work quietly in school. Make only polite small talk in the public market. Discuss little more than trades in the Hob, which is the black market where I make most of my money (p. 6).

In the example above, the fragment describes and emphasises the things that Katniss does when she wears an indifferent mask.

\section{c. Participial-phrase Fragments}

The participial-phrase fragment begins with a participle, a verb from (present or past) that functions as an adjective. The occurrences of a participle-phrase fragment in the narration of the novel begin with a present participle and a past participle. In the following example, the participialphrase fragment that occurs in the narration of the novel begins with a present participle and explains the subject in its preceding sentence:

(29) Since neither of us [Katniss and Madge] really has a group of friends, we seem to end up together a lot at school. Eating lunch, sitting next to each other at assemblies, partnering for sports activities (p. 12).

The fragment in the example above explains the subject Katniss and Madge in 
the preceding sentence. It emphasises what Katniss and Madge seem to end up doing together at school because of the lack of friends they have.

In the following examples, the participial-phrase fragments that occur in the narration of the novel begin with a past participle:

(30) I open the parachute and find a small loaf of bread. It's not the fine white Capitol stuff. It's made of dark ration grain and shaped in a crescent. Sprinkled with seeds (p. 238).

(31) And here I am a stone's throw from the biggest idiot in the Games. Strapped in a tree (p. 158).

Each fragment in the examples above also explains or adds information to the subject in the preceding sentence. The fragment in example 30 explains that the small loaf of bread that Katniss gets is sprinkled with seeds, unlike the fine white Capitol stuff. The fragment in example 31 explains that Katniss is strapped in a tree.

\section{d. Added-detail Fragments}

The added-detail fragment adds information to the preceding sentence by providing examples or details. In the narration of the novel, the added-detail fragments begin withlike, such as,especially, and except. In the following examples, the added-detail fragments that occur in the narration of the novel begin with like:

(32) Even at home, where I am less pleasant, I avoid discussing tricky topics. Like the reaping, or food shortages, or the Hunger Games (p. 6).

(33) Then, of course, I have to tell him [Peeta]. About things I've kept to myself because he was too sick to ask and I wasn't ready to relive anyway. Like the explosion and my ear and Rue's dying and the boy from District 1 and the bread (p. 292).

In example 32 , the fragment explains that the reaping, food shortages, the Hunger Games are the kinds of tricky topics that Katniss avoids at home where she is less pleasant. In example 33, explains the things Katniss has kept to herself because Peeta was too sick to ask and Katnisswas not ready to relive them.

In the following example, the added-detail fragment that occurs in the narration of the novel begins with such as:

(34) Maybe being the least prestigious, poorest, most ridiculed district in the country has its advantages. Such as, being largely ignored by the Capitol as long as we [the people of District 12l produce our coal quotas (p. 203).

The fragment in the example above explains that being largely ignored by the Capitol as long as the people of District 12 produce their coal quotas is a possible advantage of being the least prestigious, poorest, most ridiculed district in the country.

In the following example, the added-detail fragment that occurs in the narration of the novel begins with except:

(35) My father pulled me in with that remarkable voice-but I haven't sung much since he died. Except when Prim is very sick (p. 234).

The fragment above explains that Katniss has only sung when Prim is very sick ever 
since her father died. The following fragment that occurs in the narration of the novel begins with especially:

(36) My hatred of the Capitol has not lessened my hatred of my competitors in the least. Especially the Careers (p. 238).

The fragment above points out that the Careers, tributes from the wealthier districts who train throughout their lives to compete in the Hunger Games and then volunteers to participate, are the competitors that Katniss hates.

\section{e. Prepositional-phrase Fragments}

The prepositional-phrase fragment begins with a preposition placed in front of a noun or a pronoun. In the following example, the prepositional-phrase fragment that occurs in the narration of the novel begins with the preposition about and explains what Katniss is worried about:

(37) I turn and head back to the stream, feeling somehow worried. About Rue being killed, about Rue not being killed and the two of us being left for last, about leaving Rue alone, about leaving Prim alone back home (p. 213).

\section{f. Infinitive-phrase Fragments}

The infinitive-phrase fragment begins with tofollowed by a verb. The examples of an infinitive-phrase fragment that occur in the narration of the novel are as follows:

(38) I immediately wonder if this will be his strategy in the Games. To appear weak and frightened, to reassure the other tributes that he is no competition at all, and then come out fighting (p. 41).

(39) I want her [Avox girl] to stay until I fall asleep. To be there when I wake up (p. 119).

(40) I realize that if I get out of here, that will become my job. To mentor the girl from District 12 (p. 306).

(41) I want to get out of this bed. To see Peeta and Cinna, to find out more about what's been going on (p. 350).

Each fragment in the examples above explains and creates an emphasis to its preceding sentence. In example 38, the fragment explains and emphasises what Katniss thinks about the strategies that Peeta uses in the Hunger Games. In example 39, the fragment emphasises what Katniss wants the Avox girlto do. In example 40, the fragment emphasises that mentoring the girl from District 12 in the Hunger Games is the job Katniss will get. In example 41, the fragment emphasises why Katniss wants to get out of her bed.

\section{CONCLUSION}

The present study investigated the types of fragments employed in the narration of the young-adult science-fiction novel The Hunger Games written by Suzanne Collins. The fragments that were found consist of dependent-clause fragments which are subclassified into adjectival-clause fragments, adverbialclause fragments, and nominal-clause fragments, and phrase fragments which are subclassified into added-detail fragments, appositive fragments, infinitive fragments, missing-subject fragments, participialphrase fragments, and prepositional-phrase fragments.

The most common type of sentence fragment in the narration of the novel is the phrase fragment, specifically in the form of 
appositive fragment. This finding suggests that phrase fragments are more favoured to use in the novel than dependent-clause fragments. The use of phrase fragments in the narration of the novel is similar to that of dependent-clause fragments, which is to stress important points in the story or create an emphasis to a particular point, idea, or information the narrator thinks is necessary or important for the reader to know or pay attention to.

It is hoped that these findings could stress the importance of sentence fragments and contribute to a better understanding of effective use of sentence fragments in fiction writing, although they are grammatically incorrect. A limitation of the present study includes the small size of the corpus, which is from only one fiction novel. It will be of interest to study the use of sentence fragments in a larger corpus from different fiction novels and find other type of fragments in the narration besides the dependent-clause fragment and phrase fragment, perhaps a single-word fragment. Examining sentence fragments as broken sentences that obscure the narrator's intended meaning or are overused in the narration of the corpus is also recommended for further research.

\section{BIBLIOGRAPHY}

Albaugh, R. M. (1964). English: A dictionaryof grammar and structure. San Francisco, CA: Chandler.

Behrens, S. J. (2010). Grammar: A pocket guide. London, England: Routledge.

Brandon, L. (2008). At a glance: Sentences (4th ed.). Boston, MA: Cengage Learning.

Choy, P., \& Clark, D. G.(2010).Basic grammar and usage (8th ed.). Boston, MA: Cengage Learning.
Collins, S. (2008). The hunger games.New York, NY: Scholastic.

Collins English dictionary (10th ed.). (2010). Glasgow, England: HarperCollins.

Davis, C. R. (1936). Toward correct English. New York, NY: F. S. Crofts \& Co.

Denham, K., \&Lobeck, A. (2009).Linguistics for everyone: An introduction. Boston, MA: Cengage Learning.

Dickens, C. (1853).Bleak house. London, England: Bradbury \& Evans.

Fernald, J. G. (1979). English grammar simplified. London, England: HarperCollins.

Fulwiler, T., \& Hayakawa, A. R.(2003).The blair handbook (4th ed.). Upper Saddle River, NJ: Prentice Hall.

Garner, B. A.(2000).The Oxford dictionary of Americanusage and style.Oxford, England: Oxford University Press.

Gorrell, R. M., \& Laird, C. (1956).Modern English handbook. Englewood Cliffs, NJ: Prentice Hall.

Greenbaum, S., \& Nelson, G. (2002).An introduction to English grammar (2nd ed.). Essex, England: Pearson Education.

Huddleston, R., \&Pullum, G. (2005).A student'sintroduction to English grammar. Cambridge: Cambridge University Press.

Jespersen, O. (1933). Essentials of English grammar. London, England: Allen \&Unwin. 
Kline, C. R., Jr., \&Memering, W. D. (1977). Formal fragments: The English minor sentence. Research in the teaching of English, 11 (2), 97-110.

Kolln, M., \& Funk, R. (2011).Understanding English grammar (9th ed.). London, England: Longman.

MacEwan, E. J. (1900). The essentials of the English sentence. Whitefish, MT: Kessinger.

Milhorn, H. T. (2006). Writing genre fiction: A guide to the craft. Boca Raton, FL: Universal.

O'Dwyer, B. (2006). Modern English structures: Form, function, and position (2nd ed.). Peterborough, Canada: Broadview Press.

Onions, C. T. (1971). Modern English syntax (7th ed.). London, England: Routledge\&Kegan Paul.

Palahniuk, C. (2005). Fight club. New York, NY: Norton.

Rosenwasser, D., \& Stephen, J. (2011). Writing analytically (6th ed.). Boston, MA: Cengage Learning.

Schuster, E. H. (2006). A fresh look at sentence fragments. English Journal, 95 (5), 78-83.

Stilman, A. (1997). Grammatically correct: The writer's essential guide to punctuation, spelling, style, usage, and grammar. Cincinnati, OH: Writer's Digest Books.

Strunk, W., Jr., \& White, E. B. (1979).Elements of style (3rd ed.). New York, NY: Macmillan.
The American Heritage dictionary of the English language(4th ed.). (2000). Boston, MA: Houghton Mifflin. 